\title{
O POETA E A CIDADE
}

\author{
Édison José da Costa *
}

\section{Introdução}

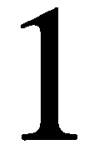

993 fornece o ensejo para comemoração que me parece cada vez mais merecida e necessária: completa-se o primeiro centenário de nasde poemas da maturidade, publicado postumamente, consolida traços e qualidades do autor: o domínio técnico, o compromisso humanista, a ligação com a cultura popular. A análise que se segue de dois poemas curtos do livro - que inclui, não se deixe de lembrar, o amazônico "Meditação sobre o Tietê" - quer insinuar leituras, despertar tentações. "Minha viola bonita" é poema de abertura que define direçōes e tonalidades de um fazer poético do qual já é concretização e "... os que esperam, os que perdem" atualiza e confirma a proposta.

* Universidade Federal do Paraná 


\title{
Trajeto
}

\section{Poema 1: "Minha viola bonita"}

O poema introduz a série que constitui Lira paulistana. Três versos heptassilábicos seguidos de verso trissilábico final compõem cada um dos quatro conjuntos estróficos. Metricamente similares, as estrofes apresentam composição sintática também equivalente, que se rompe, no entanto, a partir da metade do poema. Avança-se, assim, de um quadro inicial impregnado de harmonia para o contexto conflituoso e inquieto do encerramento. Ao movimento circular que preside o desenrolar das duas estrofes iniciais, cujos segundos versos revelam-se variaçōes melódico-entonacionais dos primeiros e cujos terceiros versos desenvolvem-se a partir do desdobramento de forma verbal com variação de pessoa, projetando-se ambas sobre o vocábulo final através da aliteração:

\author{
Minha viola bonita, \\ Bonita viola minha, \\ Cresci, cresceste comigo \\ Nas Arábias. \\ Minha viola namorada, \\ Namorada viola minha, \\ Cantei, cantaste comigo \\ Em Granada.
}

sucede, na última estrofe do poema, um andamento acumulativo que desarticula a figura rítmico-sintática inicial - a viola antes "bonita" e "namorada" está agora, significativamente, "quebrada" - marcando trocaicamente todo o segundo verso e encavalgando-o com o terceiro pelo expandir-se da série nominal enumerativa. A estrofe anterior prepara esse efeito rompendo em seu terceiro verso com a construção aliterante até ali vigente:

\footnotetext{
Minha viola ferida,

Ferida viola minha, $\mathrm{O}$ amor fugir para leste

Na borrasca.
} 
Minha viola quebrada,

Raiva, anseios, lutas, vida,

Misćria, tudo passou-se

Em São Paulo.

O fluxo poemático conhece seu encerramento dinamizando e densificando o espaço estrófico que, assim, vitaliza a associação do fazer poético à cidade de São Paulo, inserido que se encontra o poeta no respirar convulso da capital.

É cla, espaço humano contemporâneo, que lhe dá a viola que se encontra a pontear.

Poema 2: "...os que esperam, os que perdem"

Dois quartetos heptassilábicos cujos versos pares estão rimados constituem o poema. Simetricamente construída, pois primeiro e segundo versos compöem conjunto sintaticamente equivalente ao conjunto formado pelo terceiro e quarto versos, a primeira estrofe define-se como contexto vicioso, voltado sobre si mesmo, e, no entanto, vulnerável, pois inconcluso. O primeiro movimento poemático aí se configura, assentado sobre sintagmas nominais com oração principal incompleta, que se sucedem pela justaposição em série enumerativa:

...os que esperam, os que perdem

o motivo, os que emudecem,

os que ignoram, os que ocultam

a dor, os que desfalecem

As formas verbais, impondo-se em face da opacidade das formas pronominais, delineiam um quadro de intransitividade que mostra $o$ insulamento e a retraçāo: as duas únicas formas verbais transitivas da estrofe estão estrategicamente posicionadas em final de verso - o primeiro e o tereciro -, separadas metricamente do complemento que apenas no verso seguinte vem integrar a sua significação. Estas formas nominais aparecem, dessa forma, destacadas do sintagma a que sintaticamente pertencem, propondo-se, com o encavalgamento, ambigua e simultaneamente relacionadas com dois distintos conjuntos vocabulares - um no verso propositivo, outro no conclusivo. Sua carga semântica percorre medular- 
mente a estrofe, assinalando, por entre os intersticios da rede de evasāo e irrealizaçāo tecida pelo suceder acumulativo dos sintagmas sintaticamente incompletos $\mathrm{e}$ já sugerida pelas reticèncias com que o poema se inicia, o substrato que lhes sustenta a formulação e o sentido: "o motivo", "a dor".

O movimento sintático localizado na primeira estrofe espraia-se ainda pelos dois versos iniciais da segunda, desintegrando-se, todavia: perde-se a figura sintática que identificava dois conjutos de versos equivalentes e o próprio sintagma nominal se decompõe violentamente no encavalgamento estabelecido entre o primeiro e o segundo versos:

os que continuam, os que duvidam... Coraçāo,

Afirma, afirma e te abrasa

Pelas milicias do não!

O segundo e definitivo movimento estabelece-se impositivamente já no segundo verso da estrofe, interrompendo através do vocativo o movimento anterior e afirmando-se no terceiro e quarto versos pela diversidade e consistência sintaticamente configuradas. Um sentido de oposição e resistència se compōe: a forma verbal aparece repetida, articula-se imperativamente o enunciado, a forma adverbial de negação aparece substantivada $\mathrm{c}$ antiteticamente relacionada com a forma verbal. O poema năo se desfaz, na verdade, ao encerrar-se. Faz-se impulso.

\section{Conclusão}

O emprego do verso heptassilábico confere leveza e coloquialidade aos poemas analisados, de modo especial a "Minha viola bonita", que apresenta o cantador e suas cançōes. Essa caracteristica não afasta o rigor c o aprofundamento. Minucioso controle das nuanças rítmicas, sintáticas e estruturais mostram o poeta senhor de seus instrumentos, voltado para uma linguagem que, maleável, se faz precisa.

O despojamento da subjetividade e a imersão no social manifestamse enfaticamente e é na cidade que o Outro é reconhecido. São Paulo configuraçāo densa e atualizada do motivo cidade - define-se como esse espaço de participação na polaridade que a contrapōe às Arábias e a Granada, espaços de sonho e idealização nas duas estrofes iniciais de "Minha viola 
bonita". Assim, a relação do poeta com a cidade mostra-se atribulada, embora, e justamente por isso, revele-se vital, envolvente, globalizante. A procura do Outro, como se vê em "...os que esperam, os que perdem", está associada à negação do sofrimento, da omissão, ao compromisso com a realização do homem e seus valores. Exige que se resista. Exige a paixão.

\section{RESUMO}

Análise de dois poemas de Lira paulistana, de Mário de Andrade, tentando-se apreender traços de seu fazer poético na fase de maturidade.

\section{REFERÊNCIAS BIBLIOGRÁFICAS}

ANDRADE, Mário de. Poesias completas. Ed. critica de Diléa Manfio. Belo Horizonte: Itatiaia; São Paulo: USP, 1987.

LOPEZ, Telê Ponto Ancona. Mário de Andrade: Ramais e caminhos. São Paulo: Duas Cidades, 1972. 